\title{
Penanganan Lingkungan Fisik Di Objek Wisata Air Panas Desa Mengeruda, Kabupaten Ngada, Provinsi Nusa Tenggara Timur
}

Desi Deratus Adven Meo ${ }^{\mathrm{a}, 1}$, Ida Bagus Suryawan. ${ }^{\mathrm{a}, 2}$

1 advenmeo@gmail.com, ${ }^{2}$ idabagussuryawan@unud.ac.id

a Program Studi S1 Destinasi Pariwisata, Fakultas Pariwisata,Universitas Udayana, Jl. Dr. R. Goris, Denpasar, Bali 80232 Indonesia

\section{Abstract}

The tourism object of Mengeruda hot spring which located in Mengeruda village, Soa sub-district, Ngada regency is set as "Tourism Object" based on the decision letter of Ngada Regent no 7, year 2000. Besides that, the tourism object of Mengeruda hot spring have other attractions such as beautiful natural environment, but not supported by good physical environment condition, so it is necessary to make efforts or optimize the arrangement of the physical environment in the tourism object of Mengeruda hot spring.

In this research used qualitative research methods. Data collected through observation in the field or observation to know the actual condition picture related to physical environment and also interview to know the effort or optimization of arrangement of physical environment of hot water recreation object. Data were analyzed using descriptive method.

The results of this study describe the physical environment conditions both natural and artificial experiencing problems that require serious action and handling to improve the quality of the tourism object of Mengeruda hot spring. Existing problems show the tourism object of Mengeruda hot spring requires optimization of the arrangement of the physical environment according to existing planning.

Keywords : Tourism Object, Physical Environment, Optimization

\section{PENDAHULUAN}

Pariwisata merupakan suatu kegiatan dan sekaligus menjadi salah satu kebutuhan manusia. Pertumbuhan pariwisata yang sangat pesat memicu pembangunan yang bermula dari penyediaan sarana prasarana serta faktor pendukung yang ada di dalamnya. Sedangkan pariwisata menurut Undang-Undang RI No 10 Tahun 2009, adalah berbagai kegiatan wisata dan didukung berbagai fasilitas serta layanan yang disediakan oleh masyarakat, pengusaha, pemerintah, dan pemerintah daerah. Berdasarkan penjelasan yang dirangkum dari Undang-Undang RI No 10 Tahun 2009 pasal 3 dan 4 tentang Prinsip Penyelenggaraan Kepariwisataan dan Pembangunan Kepariwisataan, sebagai upaya menjaga eksistensi pariwisata dalam hal ini adalah upaya pengembangan, tidak terlepas dari rangkaian gagasan atau ide yang dihasilkan oleh para pelaku pariwisata itu sendiri, yang pada akhirnya akan memperoleh tujuan yang diinginkan. Mencapai suatu tujuan dibutuhkan sebuah perencanaan yang tidak terlepas dari segala aspek yang berhubungan dengan pariwisata.

Sebagai contoh hasil dari sebuah perencanaan yang kemudiaan disertai dengan adanya pembangunan yang baik dalam dunia pariwisata di Indonesia adalah Bali. Bercermin dari Bali yang merupakan tolak ukur kepariwisataan, wilayah atau tempat lainnya yang tengah gencar dalam mengangkat dan mengembangkan potensi pariwisatanya masingmasing sebut saja pulau Flores. Pulau Flores terletak di Provinsi Nusa Tenggara Timur merupakan salah satu tempat yang memiliki potensi alam dan terdapat pula banyak destinasi pariwisata yang indah dan layak kita kunjungi.

Terdapat sekian banyak tempat wisata yang terkenal di Pulau Flores seperti Pulau Komodo, Waerebo, Danau Tiga Warna Kelimutu serta tempat wisata lainnya, terdapat salah daya tarik wisata yang terdapat di Kabupaten Ngada yakni Objek Wisata Air Panas Mengeruda di Desa Mengeruda Kecamatan So'a. Dikatakan sebagai "Objek Wisata" karena masih mengacu pada Surat Keputusan atau SK Bupati Ngada Nomor 7 Tahun 2000 yang dikutip dari Laporan Draft Akhir Tahun RIPARDA 2015. Pengelolaan langsung ditangani oleh Pemerintah Daerah melalui Dinas terkait yakni Dinas Pariwisata dan Kebudayaan Kabupaten Ngada. Objek Wisata Air Panas Mengeruda menawarkan tempat pemandian air panas dengan sumber mata air panas mencapai suhu sekitar $45^{\circ} \mathrm{C}$, memiliki keindahan alam dan suasana yang sejuk, jauh dari keramaian serta memiliki daya tarik lainnya. Objek wisata Air Panas Mengeruda merupakan tempat yang sangat ramai dikunjungi dan paling besar memberikan pemasukan bagi Kabupaten Ngada yang terlihat 
pada data kunjungan wisata dalam Tabel 1.2

Tabel 1.2 Data Kunjungan ObjekWisata Air Panas Mengeruda

\begin{tabular}{|l|l|l|l|}
\hline \multirow{2}{*}{ Tahun } & \multicolumn{3}{|l}{$\begin{array}{l}\text { Jumlah } \\
\text { Wisata Air Panjungan }\end{array}$ Objek } \\
\cline { 2 - 4 } & Wisman & Wisnus & Jumlah \\
\hline 2011 & 3.164 & 23.976 & $\mathbf{2 7 . 1 4 0}$ \\
\hline 2012 & 3.573 & 42.416 & $\mathbf{4 5 . 9 8 9}$ \\
\hline & 3.164 & 34.343 & $\mathbf{3 7 . 5 4 1}$ \\
\hline 2013 & & 33.639 & $\mathbf{3 7 . 7 1 1}$ \\
\hline 2014 & 4.072 & 39.955 & $\mathbf{4 3 . 3 6 5}$ \\
\hline 2015 & 3.410 &
\end{tabular}

Sumber : Dinas Perhubungan, Pariwisata,komunikasi dan Informatika Kab. Ngada; 2016.

Seiring dengan berjalannya waktu, dengan jumlah kunjungan wisata dalam kategori kunjungan local tidak berbanding lurus dengan kondisi pada objek wisata Air Panas Mengeruda yang mengalami perubahan pada lingkungan fisik akibat permasalahan yang sampai dengan saat ini belum mendapatkan perhatian yang serius khusunya dari Pemerintah Daerah seperti kerusakan fasilitas utama akibat faktor utama seperti kurangnya pengawasan dan perawatan dan setidaknya menimbulkan situasi yang tidak nyaman dan terganggu dirasakan oleh sebagian besar pengunjung. (VigoNews.com. 2015).

Adapun fasilitas utama yang terdapat di Objek Wisata Air Panas Mengeruda termasuk di dalamnya adalah cottage atau penginapan yang dalam kondisi rusak dan telah lama dibiarkan. Kerusakan tersebut sudah tentu membawa dampak buruk terutama pada wajah lingkungan fisik dan juga mengurangi kualitas dari objek wisata Air Panas Mengeruda.

Berdasarkan gambaran yang ada di objek wisata Air Panas Mengeruda dan telah diketahui bersama problematika terkait dengan lingkungan fisik, maka maksud dan tujuan dari penelitian ini juga untuk mengetahui upaya atau optimalisasi serta penataan khususnya terkait lingkungan fisik dimulai dari sarana prasrana yang ada sebagaimana contohnya tentang beberapa kasus yang sebelumnya telah disebutkan yaitu kerusakan sarana prasana ataupun fasilitas pendukung di dalam objek wisata Air Panas Mengeruda untuk dioptimalkan dan dicari solusi bersama yang tepat dan baik.

\section{TINJAUAN PUSTAKA}

1. Optimalisasi

Menurut Winardi (1999) optimalisasi adalah ukuran yang menyebabkan tercapainya tujuan. Sedangkan dipandang dari sudut usaha, optimalisasi adalah usaha untuk memaksimalkan kegiatan sehingga mewujudkan keuntungan yang diinginkan atau dikehendaki. Dari uraian tersebut diketahui bahwa optimalisasi hanya dapat diwujudkan apabila dalam perwujudannya secara efektif dan efisien. Dalam penyelenggaraan pariwisata, senantiasa tujuan diarahkan dengan baik untuk mencapai hasil yang optimal.

2. Penataan

Menurut Soekadijo (2000), penataan adalah mengatur posisi objek wisata dihadapan wisatawan agar dapat menyaksikan dan menikmati bahkan melakukan kegiatan di objek tersebut. Penataan merupakan rangkaian dari menentukan, merencanakan dan memastikan bagaimana penggunaan wilayah secara proposional, sehingga area-area yang ada dapat memenuhi berbagai aspek kegiatan ekonomi, sosial budaya dan lingkungan fisik. Dimanapun kawasan objek wisata dibina, tata lingkungan fisik atau lingkungan alam di sekitarnya selalu menjadi tumpuannya

3. Daya tarik wisata

Daya tarik wisata menurut Suwardjoko P. Warpani dan Indira P. Warpani (2007) adalah segala sesuatu yang memicu seseorang atau sekelompok orang mengunjungi suatu tempat karena sesuatu yang memiliki makna tertentu, misalnya: lingkungan alam, peninggalan atau tempat sejarah, peristiwa tertentu. Sedangkan menurut Gamal Suwantoro (1997) umumnya daya tarik suatu objek wisata berdasarkan pada:

a. Adanya sumber daya yang dapat menimbulkan rasa senang, indah, nyaman, dan bersih.

b. Adanya aksesibilitas yang tinggi untuk dapat mengunjunginya.

c. Adanya ciri khusus yang bersifat langka. d. Adanya sarana prasarana penunjang untuk melayani para wisatawan yang

hadir. 
e. Objek wisata alam mempunyai daya tarik

tinggi karena keindahan alam pegunungan, sungai, pantai, hutan dan sebagainya.

f. Objek wisata budaya mempunyai daya tarik tinggi karena memiliki nilai khusus dalam bentuk atraksi kesenian, upacaraupacara adat, nilai luhur yang terkandung dalam suatu objek buah karya manusia pada masa lampau.

Berdasarkan uraian tersebut dapat disimpulkan bahwa daya tarik wisata merupakan dasar bagi kepariwisataan, tanpa adanya daya tarik disuatu daerah atau tempat tertentu, kepariwisataan akan sulit untuk dikembangkan.

4. Lingkungan Fisik

Alister Mathison dan Geoffery Wall (1982) guna menjaga keberkanjutan pariwisata dalam pembangunan kepariwisataan perlu memperhatikan beberapa aspek indikator yang memiliki peran penting yakni aspek lingkungan fisik. Terdapat dua kategori indikator lingkungan dari komponen fisik yang memerlukan pengamatan dan pengukuran secara periodik, yaitu:

1) Lingkungan fisik yang bersifat fixed; yaitu berupa sumberdaya alam atau ekologi bukan buatan manusia, seperti lanskap, hutan, danau, ketersediaan air tanah, polusi udara, terumbu karang, flora dan fauna dan sebagainya.

2) Lingkungan fisik yang bersifat flexsible; yaitu berupa sumber daya buatan, seperti: sistem sarana prasarana, infrastruktur, water supply, pembuangan limbah, jaringan listrik, transportasi, pos dan telekomunikasi, layanan kesehatan, perbankan, restoran, cinderamata dan sebagainya.

5. Perencanaan Pariwisata

Perencanaan menurut Spillane, (1994) merupakan suatu rangkaian kegiatan untuk mencapai suatu tujuan di masa mendatang dengan mengelola sumber daya dan potensi yang ada. Suatu perencanaan terdiri dari beberapa rangkaian kegiatan dan juga proses yang dilakukan untuk mencapai suatu tujuan yang telah ditentukan untuk masa depan yang lebih baik dari masa sekarang dengan mengelola dan mengoptimalkan potensi atau sumber daya yang ada sebaik mungkin. Dalam suatu konsep perencanaan wisata, para pengembang harus memperhatikan semua aspek pendukung pariwisata, karena pariwisata merupakan kegiatan yang berlangsung di atas permukaan tanah dan menyangkut semua bentuk bentuk unsur alam, air, udara, kehidupan liar didalamnya, bentang alam, hutan, iklim, sungai, laut, pantai dan lainnya. Selain faktor alam terdapat pula faktor-faktor lainnya yaitu faktor buatan manusia seperti pasar, transportasi dan karakteristik masyarakat setempat.

\section{METODE}

Penelitian ini mengambil lokasi di objek wisata Air Panas Mengeruda di Desa Mengeruda, Kecamatan So'a, Kabupaten Ngada, Provinsi Nusa Tenggara Timur. Objek Wisata Air Panas Mengeruda terdapat di desa Mengeruda, Kecamatan Soa, Kabupaten Ngada, Propinsi Nusa Tenggara Timur. Secara geografis objek wisata Air Panas Mengeruda terletak pada ketinggian \pm 700 meter diatas permukaan laut dan berbatasan dengan beberapa wilayah desa lainnya. Untuk sampai ke Objek Wisata Air Panas Mengeruda dapat menggunakan kendaraan pribadi maupun dengan angkutan umum. Oleh sebagian besar masyarakat sekitar mengenal nama angkutan umum tersebut dengan sebutan "Bemo". Jarak dari kota Bajawa dapat ditempuh dengan angkutan atau transportasi umum dengan rute Bajawa-So'a serta dari bandara berjarak 1 kilometer. Mengidentifikasi peroblematika terkait dengan lingkungan fisik saat ini yang perlu di optimalkan lebih baik lagi di Objek Wisata Air Panas Mengeruda di Kabupaten Ngada, Provinsi Nusa Tenggara Timur terutama peroblematika yang menjadi fokus perhatian yakni. Lingkungan fisik yang sifatnya fixed atau alami bukan buatan manusia maupun flexsible ataupun buatan manusia seperti: sistem sarana prasarana, infrastruktur dan lain sebagainya yang ada di objek wisata Air Panas Mengeruda. Selain itu juga perlu mengidentifikasi faktor penyebab problematika yang ada. menguraikan upaya atau penanganan dalam bentuk optimalisasi penataan lingkungan fisik baik yang bersifat fixed maupun fleksible di Objek Wisata Air Panas Mengeruda di Kabupaten Ngada, Provinsi Nusa Tenggara Timur. 
Sumber data yang digunakan dalam penelitian ini adalah data primer maupun data sekunder. Data Primer yang dimaksud dalam penelitian ini adalah Data primer diperoleh secara langsung dari sumber pertama atau dengan tidak melalui media perantara, seperti media observasi maupun wawancara (Umar, 2013) Data primer didapat dari hasil wawancara dengan pengelolah objek wisata Air Panas Mengeruda adalah Pemerintah Daerah melalui Dinas Pariwisata dan Kabudayaan Kabupaten Ngada, sedangkan data sekunder yang dimaksud adalah data yang diperoleh dari dokumentasi di objek wisata Air Panas Mengeruda, data atau laporan yang sudah tersedia yakni data atau laporan perencanaan dalam menjawab problematika yang ada salah satunya adalah RIPARDA (Rencana Induk Pembangunan Pariwisata Daerah) Kabupaten Ngada dan hasil- hasil penelitian yang telah ada sebelumnya

Metode pengumpulan data yang dilakukan adalah observasi, wawancara dan studi dokumentasi. Observasi dilakukan untuk mengetahui kondisi real terutama pada kondisi lingkungan nfisik yang diketahui terdapat 2 (dua) jenis atau sifat lingkungan fisik yakni fixed (alami) dan pun flexsible (buatan manusia). Wawancara dilakukan dengan Kepala Dinas Pariwisata dan Kabudayaan Kabupaten Ngada, Kepala Desa Mengeruda, wisatawan dan masyarakat untuk mendapati sumbangan informasi dan sebagai landasan menemukan fakta yang ada di lapangan, maka maka maksud dari wawancara tersebut untuk mengetahui penjelasan secara langsung terkait problematika terkait lingkungan fisik dan faktor penyebab atau kerusakan fasilitas yang sangat jelas terlihat. Studi pustaka serta dokumentasi digunakan untuk melengkapi dan mendukung hasil di lapangan yang berupa data yang bisa langsung digunakan seperti data kunjungan wisata, data kependudukan masyarakat Desa Mengeruda, gambaran umum objek wisata Air Panas Mengeruda dan hasil dokumentasi untuk mengetahui secara pasti terkait problematika lingkungan fisik.

Penentuan Informan dalam penelitian ini menggunakan teknik penentuan informan Purposif Sampling yaitu menentukan kriteria serta informan yang dianggap kredibel atau mengetahui secara pasti topik penelitian atau problematika yang ada. Dalam penelitian ini yang dimaksud adalah Teknik analisa data yang digunakan dalam laporan penelitian ini adalah teknik analisis data kualitatif. Teknik analisis data kualitatif menurut Miles dan Huberman (1992) dalam (Sugiyono, 2012) dimana model analisis ini dilakukan pada periode tertentu setelah selesai pengumpulan data. Aktivitas dalam menganalisis data yaitu dengan reduksi data, penyajian data dan penarikan kesimpulan. Pada penelitian ini juga menggunakan teknik analisis data deskriptif kualitatif. Sukmadinata (2009), menyatakan bahwa penelitian deskriptif bertujuan mendefinisikan suatu keadaan atau fenomena secara apa adanya. Dari analisis datra yang ada dalam penelitian ini memperoleh informasi serta data yang sesuai terkait problematika lingkungan fisik dan terkait tindaklanjut melalui cara mengatasi problematika lingkungan fisik yang telah ditemukan dilapangan dengan upaya optimalisasi serta penataan yang lebih baik melalui perencanaan yang tengah disiapkan untuk dilaksanakan agar dapat tercapai tujuan bersama.

\section{HASIL DAN PEMBAHASAN \\ 4.1 Gambaran Umum Objek Wisata Air Panas Mengeruda}

Objek Wisata Air Panas Mengeruda terdapat di desa Mengeruda, Kecamatan Soa, Kabupaten Ngada, Propinsi Nusa Tenggara Timur. Mencari serta mengetahui letak atau keberadaan dari objek wisata Air Panas Mengeruda maka perlu diketahui terlebih dahulu wilayah keseluruhan dari Kabupaten Ngada secara keseluruhan termasuk Kecamatan So'a tempat dimana objek Wisata Air Panas Mengeruda berada yang digambarkan pada peta 


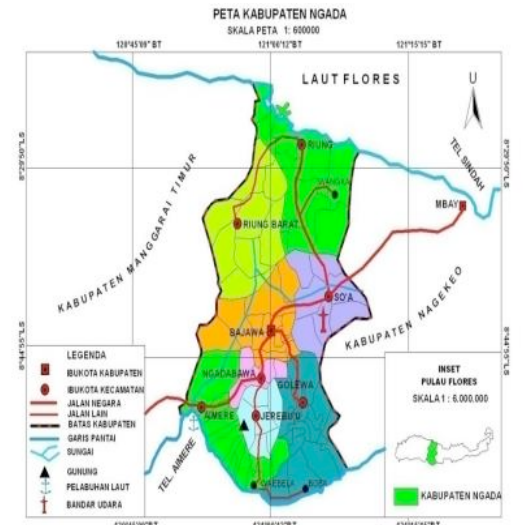

Gambar 4.1 Peta Kabupaten Ngada

Sumber: Laporan Draft Akhir RIPARDA Kabupaten Ngada 2015

Keberadaan objek wisata Air Panas Mengeruda yang terletak di Desa Mengeruda. Air Panas Mengeruda secara resmi ditetapkan sebagai Objek Wisata melalui Surat Keputusan Bupati Ngada nomor 7 tahun 2000 dan berada di bawah pengawasan dan Pengelolaan Dinas Pariwisata dan Kebudayaan Kabupaten Ngada. Status pengembangan dari objek wisata Air Panas Mengeruda telah berkembang.

Objek wisata Air Panas Mengeruda merupakan objek wisata yang menawarkan pemandangan alam yang sangat indah, di samping pemandangan alamnya yang indah, tempat ini menawarkan tempat pemandian air panas dengan sumber mata air panas mencapai suhu sekitar $45^{\circ} \mathrm{C}$. Sumber air panas ini keluar dari perut bumi berasal dari letusan gunung berapi Inelika yang merupakan salah satu gunung berapi yang jarak atau radiusnya yang cukup dekat yakni \pm 5 kilometer.

Desa mengeruda sebagai letak objek wisata Air Panas Mengeruda memiliki jumlah penduduk 13.418 jiwa, terdiri dari 6.611 lakilaki dan 6.807 perempuan, hal tersebut juga terjadi pada di Desa Mengeruda yang termasuk dalam wilayah kecamatan So'a yang menunjukan jumlah penduduk laki-laki adalah 611 jiwa dan jumlah penduduk perempuan adalah 606 jiwa belum termasuk jumlah keseluruhan jika dihitung dengan jumlah anakanak yang ada di Desa Mengeruda dan bermata pencaharian sebagai petani. (sumber: Badan Pusat Statistik Kabupaten Ngada, Statistik Daerah Kecamatan Soa Tahun 2015)

Keberadaan objek wisata Air Panas Mengeruda dengan segala potensi yang dimilikinya tentunya sangat menarik perhatian wisatawan untuk mengunjungi objek wisata
Melihat Air Panas Mengeruda. Kunjungan wisata ke objek wisata Air Panas Mengeruda dilihat jumlahnya meningkat dalam kategori kunjungan lokal. Tingginya kunjungan tersebut belum berbanding lurus dengan pelayanan dan penataan kawasan ini menjadi obyek wisata Air Panas Mengeruda yang nyaman dan bermutu karena adanya permasalahan yang perlu ditangani secara serius dan berkelanjutan. Peroblematika yang ditemukan seakan sudah menjadi pemandangan yang biasa pada saat ini. Kerusakan beberapa fasilitas utama seperti ruang ganti pakaian dan penginapan dibiarkan tanpa ada tindak lanjut karena kurangnya pengawasan serta perawatan yang baik dari pihak pengelolah yang jumlahnya juga sangat terbatas atau minim memiliki tenaga atau sumber daya manusia yang profesional untuk mengelolah dan melakukan penanganan yang baik terhadap masalah yang ada. Permasalahan lainnya adalah masalah kebersihan yang kurang baik dan terkesan kumuh akibat aktifitas atau kegiatan wisata oleh pengunjung yang kurang sadar akan arti pentingnya menjaga lingkungan.

\subsubsection{Gambaran Kepariwisataan Objek Wisata Air Panas Mengeruda}

\section{A. Attraction/ Atraksi}

Selain keunggulan, keunikan serta keindahan alam dari objek wisata Air Panas Mengeruda kehidupan sosial budaya masyarakat So'a termasuk di dalamnya masyarakat Desa Mengeruda sangat menjunjung tinggi nilai-nilai budaya yang diwariskan oleh leluhur dengan tetap memegang erat tradisi turun temurun yang tetap bertahan sampai dengan saat ini seperti tradisi berburu yang dalam istilah adat setempat (Parawitu) adalah tradisi yang rutin dilakukan setiap bulan oktober serta tradisi Tinju Adat (Sagi) sebagai tradisi yang wajib untuk dilakukan sebagai perayaan syukur panen yang pada dasarnya penduduk bermata pencaharian sebagai petani. Terdapat juga situs purbakala Cekungan So'a yang berada di daerah Matamenge sebagai lokasi penggalian binatang purba seperti fosil gajah puba (stegodon), fosil tikus purba, gading, ular, dan serpihan gerabah dari zaman purba yang letaknya tidak jauh dari objek wisata Air Panas Mengeruda yang kemudian hasil penggalian akan diletakan di museum objek wisata Air Panas Mengeruda yang tengah dalam tahap pembangunan sebagai daya tarik penunjang yang memiliki nilai edukasi. 


\section{B. Amenities / Fasilitas}

Adapun fasilitas yang disediakan di objek wisata Air Panas Mengeruda adalah: loket karcis, areal parker yang cukup luas untuk kendaraan roda dua maupun empat, ruang ganti pakian, toilet dan MCK, cottage atau penginapan, gedung convention centre, kolam renang buatan, gazebo atau rumah payung.

Secara umum banyak fasilitas tidak dapat berfungsi sebagaimana mestinya sebagai contoh fasilitas ruang ganti yang sudah tidak layak pakai dan rusak sehingga wisatawan atau pengunjung merasa kebingungan untuk mencari tempat ganti pakian yang tersedia di beberapa titik yang memungkinkan masih dapat di gunakan, toilet yang tidak terjaga kebersihannya serta fasilitas toilet yang sudah rusak, kurangnya jumlah tempat sampah sehingga sampah-sampah yang terkumpulkan sesekali dibakar padahal hal tersebut sangat berbahaya bagi lingkungan sekitar jika kurang pengawasan, rusaknya fasilitas gedung serbaguna serta cottage atau penginapan dalam objek wisata tersebut sama sekali tidak bisa digunakan lagi dan tersisah runtuhan atau serpihan material bangunan seperti kayu papan dan lainnya sehingga wistawan dalam hal ini seperti wisatawan mancanegara tidak mempunyai cukup banyak waktu atau menginap untuk menikmati objek wisata ini tetapi harus menginap di kota Bajawa yang cukup banyak menyediakan jasa akomodasi seperti penginapan atau hotel.

\section{Ancyllary/Pengelolaan}

Pemerintah daerah mengambil alih pengelolaan sejak tahun 2000 sejalan dengan air panas mengeruda secara resmi ditetapkan sebagai "Objek Wisata" melalui Surat Keputusan Bupati Ngada Nomor 7 tahun 2000 di bawah pengawasan dan pengelolaan Dinas Pariwisata dan Kebudayaan Daerah Kabupaten Ngada. Pengelolaan objek wisata Air Panas Mengeruda memanfaatkan jumlah tenaga kerja yang trdiri dari 1 karyawan atau pegawai pada Dinas Pariwisata dan Kebudayaan Kabupaten Ngada, masyarakat lokal yang terdiri dari 4 orang sehingga berjumlah 5 orang. Penetapan tenaga kerja yang pada posisinya berada di objek wisata Air Panas Mengeruda dengan jumlah 5 orang secara tidak langsung menunjukan minimnya sumber daya manusia dalam mengelolah dan bertanggungjawab dalam kegiatan sehari-hari di objek wisata Air Panas Mengeruda. Tenaga kerja yang berasal dari 4 orang mayarakat lokal tidak menerima upah dari anggaran biaya atau honor pengelolaan objek tersebut melainkan menerima upah yang diberikan oleh Pemerintah dari anggaran atau biaya kebersihan dan pemeliharaan yang dialihkan untuk tenaga kerja masyarakat lokal.

\section{Accesibility/Aksebilitas}

Obyek wisata Air Panas Mengeruda terletak di desa Mengeruda, Kecamatan Soa. Jaraknya \pm 25 kilometer dari Kota Bajawa. Dari kota Bajawa dapat ditempuh dengan kendaraan pribadi maupun umum dengan waktu sekitar 30 menit untuk menuju objek wisata Air Panas Mengeruda berjarak $1 \mathrm{~km}$ dari bandara Turelelo So'a Bajawa sebgai akses penghubung jalur penerbangan dengan bandara Eltari Kupang dan Komodo Labuan Bajo. Infrastruktur jalan sepanjang kota Bajawa, ataupun dari bandara menuju objek wisata Air Panas Mengeruda memiliki akses yang sangat baik karena memiliki jalan dengan aspal yang halus dan cukup lebar serta adanya rambu- rambu penunjuk arah yang begitu memadai.

\subsection{Problematika lingkungan fisik yang ada di objek wisata Air Panas Mengeruda}

\subsubsection{Problematika Lingkungan Fisik}

Problematika yang dimaksudkan dan nampak terlihat serta dirasakan saat ini pada objek wisata Air Panas Mengeruda adalah problematika terkait lingkungan fisik yang bersifat fixed, yaitu berupa sumber daya alam atau ekologi bukan buatan manusia, ketersediaan air tanah dan lainnya serta menunjukan lingkungan fisik yang bersifat flexsible. Bersifat flexsible dalam arti lingkungan fisik yang berupa sumber daya buatan manusia.

Problematika terkait lingkungan fisik yang di temukan di lapangan yakni di objek wisata Air Panas Mengeruda adalah:

\section{A. Problematika lingkungan fisik bersifat fixed:}

Kebersihan pemandian air panas tidak terjaga. Pemandangan tersebut sering terlihat dan mengganggu kesan indah dan alami di objek wisata Air Panas Mengeruda. Tidak terjaganya lingkungan atau terlihat kotor karena sering berserakan sampah diberbagai tempat dalam kawasan objek wisata Air Panas Mengeruda. Sampah-sampah yang sering ditemukan seperti sampah plastik, botol minuman, kemasan shampoo dan sabun, 
bungkusan rokok, bungkusan makanan serta sampah dedaunan yang setiap harinya berjtuhan karena di kawasan sekitar banyak ditumbuhi pepohonan besar dan semak belukar yang lebat.

Problematika saat ini dan salah satunya terkait sampah atau kebersihan lingkungan akan memicu permasalahan jangka panjang seperti : Pencemaran air panas akibat sampah yang mengandung zat-zat kimia dari kemasan shampo dan sabun, menurunnya kebersihan dan kejernihan air panas akibat kegiatan wisata atau kunjungan masal, terutama pada hari sabtu dan minggu atau akhir pekan, adanya perilaku masyakat yang membiarkan ternak seperti sapi yang bebas berkeliaran dan memakan tumbuhan sekitar kawasan objek wisata Air Panas Mengeruda.

\section{B. Problematika lingkungan fisik bersifat flexsible:}

Fasilitas telah rusak tidak terawat dengan baik seperti fasilitas ruang ganti, toilet dan fasilitas penginapan yang tidak berfungsi dan berbengkelai

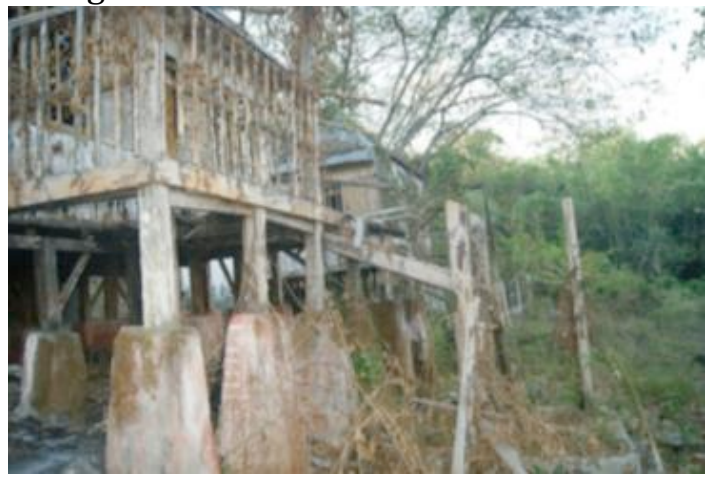

Gambar 4.15 Penginapan yang rusak Sumber: Hasil Penelitian Agustus 2017

Selain problematika terkait dengan lingkungan fisik adapun problematika lain yang mempunyai pengaruh yang dapat membawa dampak buruk pada objek wisata Air Panas Mengeruda berdasarkan Laporan Draft Akhir RIPARDA Kabupaten Ngada Tahun 2015 yaitu: Tidak memiliki Sumber Daya Manusia (SDM) profesional yang memadai untuk mengelola objek wisata Air Panas Mengeruda, tidak adanya managemen pengunjung dalam hal ini ditemukan beberapa prilaku pengunjung yang kurang baik termasuk masyarakat lokal yang tidak mematuhi kewajiban membayar karcis, tidak adanya fasilitas asuransi yang menjamin keselamatan jiwa dari pengunjung selama berada di objek wisata Air Panas Mengeruda.

\subsubsection{Faktor-faktor yang penyebab terjadinya problematika pada lingkungan fisik yang bersifat fixed maupun flexible \\ Faktor-faktor penyebab terjadinya} permasalahan terkait lingkungan fisik baik yang bersifat fixed maupun flexsible adalah: Pembangunan tanpa memperhitungkan dampak jangka panjang, minim dan bahkan tidak ada sumber daya manusia dalam hal ini sumber daya manusia yang bersifat profesional atau tenaga ahli yang berkompeten untuk mengelolah objek wisata Air Panas Mengeruda, tidak adanya sinergi stakeholder yang ada di objek wisata Air Panas Mengeruda, rendahnya sadar wisata masyarakat, kurangnya pengawasan dan pemeliharaan akibat terbatasnya jumlah tenaga kerja, perilaku menyimpang pengunjung atau masyarakat lokal, fenomena alam atau cuaca buruk yang sering terjadi.

\subsection{Penanganan Lingkungan Fisik di Objek Wisata Air Panas Mengeruda.}

Langkah atau upaya yang diambil tentunya dengan melihat problematika yang ada serta faktor - faktor penyebabnya sebagai dasar pertimbangan melakukan optimalisasi penataan lingkungan fisik agar dapat meningkatkan kualitas kepariwisataan yang ada serta mambawa dampak yang baik terhadap aspek lain seperti dampak sosial ekonomi serta sosial budaya selain lingkungan fisik di objek wisata Air Panas Mengeruda.

Penanganan lingkungan fisik di objek wisata Air Panas Mengeruda dapat dilakukan melalui: Perencanaan penataan lingkungan fisik dengan berpedoman pada Rencana Induk Pembangunan Pariwisata Daerah (RIPARDA) yang pada saat itu digarap oleh tim dari pusat pariwisata Universitas Gajah Mada Jogjakarta (UGM) yang tengah digarap dilanjutkan dengan menggarap RIPO (Rencana Induk Pembangunan Obyek). Penelitian ini memberikan input terkait perencanaan penataan lingkungan fisik yang bersifat fixed (alam) maupun flexsible (buatan) sebagai dasar pertimbangan stakeholders yang telibat di dalamnya terutama bagi pengelolah dengan tujuan untuk meningkatkan kualitas objek wisata Air Panas Mengeruda yakni:

a) Penataan lingkungan fisik bersifat fixed (alam)

Penataan lingkungan fisik yang bersifat 
alami selain berlandaskan pada problematika atau permasalahan terkait juga menempatkan fokus perhatian pada pemanfaatan luas kawasan atau areal objek wisata Air Panas Mengeruda secara keseluruhan yang diketahui 5 hektar menyisahkan setidaknya beberapa titik lainnya maka perlu dilakukan.

Penetapan titik sterilisasi arus alur sungai dengan dengan pemanfaatan teknologi tepat guna seperti alat penyaringan air dengan tujuan tetap menjaga kebersihan atau kualitas kejernihan air sekaligus meningkatkan khasiat kesehatan air panas yang dipercaya dapat meyembuhkan penyakit kulit, dengan pertimbangan adanya sumber mata air panas yang bersal dari luar yang kemudian bercampur seperti kondisi saat ini untuk mengantisipasi salah contoh kasus prilaku masyarakat yang membiarkan ternak berkeliaran bahkan memandikan ternak seperti sapi disungai yang memiliki satu arus atau alur menuju ke dalam objek wisata air panas yang membawa lumpur bahkan sampah. penataan ruang terbuka hijau didalam kawasan objek wisata Air Panas Mengeruda.

b) Penataan lingkungan fisik bersifat flexsible (buatan)

Perencananaan dan pengembangan lebih lanjut lebih memusatkan perhatian pada kondisi fasilitas beberapa fasilitas utama yang sifatnya menjadi kebutuhan penting tapi sudah tidak optimal karena dalam kondisi rusak tidak terpakai seperti:

Pemanfaatan kembali cottage atau penginapan apabila dana mencukupi untuk melkukan perbaikan, Penyediaan kamar mandi khusus dan toilet penyediaan fasilitas dari kamar mandi dan toilet sesuai dengan fungsinya masing - masing, perbaikan kembali kolam renang buatan, penataan kembali tembok yang mengisolasi seluruh kawasan objek wisata Air Panas Mengeruda dengan arsitektur atau rancangan yang menggunakan karakteristik budaya setempat, perluasan lahan parkir untuk mengantisipasi jumlah kendaraan pengunjungan dalam kunjungan masal disetiap akhir pekan yang sangat tinggi.

Optimalisasi juga perlu memperhatikan hal lain yang bersifat umum karena saling berkaitan dengan dan memberikan manfaat pada aspek kehidupan lainnya yang perlu dilakukan yakni: Penyiapan Sumber Daya Manusia (SDM), peningkatan pengawasan dan keamanan, pemeliharaan terhadap fasilitas sarana prasarana, peningkatan sosialisasi oleh pemerintah daerah yang sekaligus adalah pengelolah, monitoring dan evaluasi, Pendanaan Terhadap Kegiatan Pengembangan atau Penataan Lingkungan Fisik Objek Wisata Air Panas Mengeruda.

\section{SIMPULAN DAN SARAN}

\subsection{Simpulan}

Kualitas dari objek wisata Air Panas Mengeruda terkesan bermutu rendah akibat problematika terkait lingkungan fisik. Problematika lingkungan fisik yang ada di objek wisata Air Panas Mengeruda adalah Problematika lingkungan fisik yang bersifat fixed (sumber daya alam) dan fleksible (buatan). Keduanya digambarkan secara real berdasarkan kondisi saat ini seperti rusaknya berbagai macam fasilitas utama dan pendukung yang terdapat di objek wisata Air Panas Mengeruda, masalah kebersihan dan problematika lainnya yang dirasakan oleh sebagian besar pengunjung atau wisatawan yang sangat terganggu dan mengurangi kesan indah. Pengawasan, tingkat keamanan dan pemeliharaan yang rendah dari pihak pengelolah yang diketahui pengelolaan objek wisata Air Panas Mengeruda sepenuhnya diambil alih oleh Pemerintah Daerah melalui Dinas Pariwisata dan Kebudayaan Kabupaten Ngada sehingga terlihat dalam pengelolaannya minim sumber daya manusia yang profesional dalam mengelolah objek wisata Air Panas Mengeruda terlihat belum optimal dalam hal penataan lingkungan fisik di objek wisata Air Panas Mengeruda.

Menjawab problematika yang ada dan terkait optimalisasi penataan lingkungan fisik di objek wisata Air Panas Mengeruda telah direncanakan oleh Dinas terkait yakni Dinas Pariwisata dan Kebudayaan Kabupaten Ngada dengan pembuatan RIPO (Rencana Induk Pembangunan Obyek) yang akan datang sehingga penelitian ini lebih kepada memberikan solusi atas suara bersama terkait langkah-langkah atau upaya optimalisasi yang memungkinkan 
efektif dan secara khusus dan menjadi sumabangan ide dari peneliti yang memungkinkan untuk dilakukan seperti pada lingkugan fisik yang bersifat fixed (alami) yakni: penetapan titik sterilisasi arus alur sungai, penempatan titik penampungan dan pemusnahan sampah, penataan taman atau ruang hijau di dalam objek wisata air panas mengeruda. Sedangkan pada lingkugan fisik yang bersifat flexsibel (buatan) Perbaikan dan pemanfaatan kembali cottage atau penginapan, Penyediaan kamar mandi khusus dan toilet, Perbaikan kembali kolam renang buatan, Penataan kembali tembok isolasi seluruh kawasan objek wisata Air Panas Mengeruda, Perluasan lahan parkir.

Penanganan lingkungan fisik dengan optimalisasi yang secara khusus menempatkan fokus perhatian pada penataan lingkungan fisik tidak terlepas pada hal lain seperti: penyiapan sumber daya manusia, peningkatan pengawasan dan keamanan, pemeliharaan terhadap fasilitas atau sarana prasarana, sosialisasi, monitoring dan evaluasi, pendanaan terhadap kegiatan pengembangan atau penataan lingkungan fisik objek wisata Air Panas Mengeruda.

\subsection{Saran}

Melihat problematika yang ada maka dalam perencanaan yang kemudian dilakukan kembali langkah pembangunan dan pengembangan sangat perlu menempatkan focus perhatian pada lingkungan fisik yang bersifat alami maupun buatan terutama pada problematika terkait kebersihan lingkungan dan nampak terlihat adalah terkait kerusakan fasilitas. Terkait hal tersebut juga sangat dibutuhkan perhatian yang penuh melalui pengawasan yang baik dari pengelolah serta peliharaan terhadap fasilitas yang ada atau telah diperbaiki maupun terhadap pengunjung.

\section{DAFTAR PUSTAKA}

Alister Mathison and Geoffery Wall (1982). Tourism: Ekonomic, Physical And Sosial Impacts, Singapore: Longman Publisher.

Laporan Draft Akhir tahun dan Data Wisatawan Kabupaten Ngada. 2016. Bajawa: Dinas Perhubungan, Pariwisata, Komunikasi dan Informatika Kab. Ngada.

Laporan akhir RIPARDA ( Rencana Induk Perencanaan Pariwisata Daerah). 2015. Bajawa: Dinas Pariwisata dan kebudayaan Kab. Ngada.

Miles, B. Mathew dan Michael Huberman. 1992. Analisis Data Kualitatif Buku Sumber Tentang Metode-Metode Baru, Jakarta: UIP.

Soekadijo,R.G. (2000) Anatomi Pariwisata (Memahami Pariwisata Sebagai "Systemic Linkage"). Jakarta: PT Gramedia Pustaka Utama.

Statistik Daerah Kecamatan Soa. 2015. Bajawa:Badan Pusat Statistik Kabupaten Ngada.

Sugiyono. 2012. Metode Penelitian Kuantitatif, Kualitatif dan $R \& D$. Bandung: Penerbit Alfabeta.

Sukmadinata, Nana Syaodih.2009. Metode Penelitian Pendidikan. Bandung: PT Remaja Rosdakarya

Suwantoro, G. (1997). Dasar-Dasar Pariwisata. Yogyakarta: Andi

Undang-Undang Republik Indonesia Nomor 10 tahun 2009 tentang Kepariwisataan.

Warpani. P. Suwardjoko \& Warpani. P. Indra. (2007) Pariwisata Dalam Tata Ruang Wilayah. Bandung : Penerbit ITB, 2007.

Winardi, 1999. Pengantar Managemen Penjualan. Bandung: PT. Citra Aditya Bakti.

Sumber Internet :

http://www.VigoNews.com.berita/ Jumat/16/ Oktober/ 2015/objek-wisata-terkesan-kumuh.html

Diunduh April 2016 pada jam 20 : 25 WITA 